\title{
Case Study: Exploring Golden Age Students' Ability and Identifying Learning Activities in Kindergarten
}

\author{
M Rohmadi ${ }^{1}$, M Sudaryanto ${ }^{2}$, C Ulya ${ }^{3}$, H S Akbariski ${ }^{4}$, U R Putri $^{5}$ \\ $1,2,3,4,5$ Universitas Sebelas Maret, Surakarta \\ 1mamad_r76@staff.uns.ac.id., ${ }^{2}$ memetsudaryanto@staff.uns.ac.id.. ${ }^{3}$ chafit@staff.uns.ac.id, \\ habibsafillah@gmail.com, ${ }^{5}$ ulfakiky@student.uns.ac.id
}

\begin{abstract}
Children or young learners' cognitive development must be built early because their age is in the golden period, early learning is used to find out how children learn. The children's cognitive development is adjusted to the age of the child because each child has a different development. Data collection techniques in this research in the form of interviews and observations. The interview is a process of collecting data through questioners and interviewees. The purpose of the interview is to find out in depth the appropriate method of teaching children or young learner. In addition, the interview aims to find out the children's problems at the time. Every child is born with different abilities, be it intelligence, talent, physical strength, and social skills. Therefore, in educating their students, teachers certainly find convenience and difficulty. The ease that is found in early childhood or young learner teachers is innocence in children. The innocence of children makes it easy for teachers to provide understanding and instill a thing for whatever reason the child will accept it. Student learning methods are used in a balanced way. Balanced learning will produce student assessment instruments. However, student learning methods are also flexible in that their use is adapted to the character of each child.
\end{abstract}

Keywords:Kindergarten, Golden Age, Student Needs

\section{INTRODUCTION}

Early childhood is a time when a child has not been able to develop his potential independently. Children will tend to be happy to spend time by playing, having high imagination, finding out new things around, and imitating the roles they see from their family and environment [1]. At this time, parents' role in assisting children to accept new things is essential so that children remain in the development that they should. In addition to the role of parents, the role of early educators is also needed to optimize children's development through early childhood education institutions.

Early childhood are children aged five years and under who are in a complex stage of growth and development, both physically and mentally. Early childhood is often referred to the golden age, or the best time to instill the basis of knowledge and personality [2]. During the golden age, children will be very responsive to accept new things and immediately embedded in themselves that will affect the development of the children's personality. Therefore, at the age of golden age, it is essential to instill good life values for the children. 
Education has an integrated system for the implementation of optimal education that is developing the knowledge, attitudes, skills, and intellectuals of an individual. The education system is used as a reference to control all aspects of education in order to achieve educational goals. Whereas early education is a form of education that focuses on physical, intellectual and mental development in the children. In early education, there is a special system on how to educate children with simple learning methods so that they are easily captured by the children [3]. These learning methods are usually varied in the form of games, singing, and direct interaction with the local natural and social environment. Variation of learning is one of the strategies for children to be interested in learning in school.

Children's cognitive development must be built early because the child's age in the golden period, early learning is used to find out how children learn. The way children learn to determine the methods that will be applied to the children. After knowing the right method, the learning received by a child will certainly be maximal because it is in accordance with the child's potential. Children's cognitive development is adjusted to the age of the child because each child has a different development [4].

In addition to cognitive development, motor development must also be sharpened since the children is in their golden age. Motor development is the development in children which includes the skills of grasping, standing, walking, moving their legs and so on. Children's motor development is taught to children from an early age so that it is easy to identify their significant development. The children's motor development is side by side with the children's cognitive development.

Specific methods in early education are intended so that children do not get bored easily in the learning process, because basically early childhood have not been able to process their mood well. This results in the children only being able to express their feelings by refusing to do something without being able to explain. Therefore, modification of educational methods is needed to overcome the unexpected things that happen to the children [5]. The specific method used is also an effort to maximize students' achievement. However, maximizing achievement is applied after the educator knows the method that suits the character of the children/young learner.

Learning with the modification of the method is expected to improve students' motor and cognitive skills. In addition, the special method used will certainly increase the ability of students to socialize. Re-actualizing the role of the teacher is a way for children to be synchronized and directed in early childhood education. The teacher has several roles as a facilitator, communicator, education waiter, children's imagination developer, motivator, evaluator, consultant and counseling for children in school [6]. Professional teachers must play the role maximally so that their students can develop optimally as well.

All the roles of the teacher are important, but the most important thing in educating young children is the role as a provider of imagination and motivation. That is because at the age of the play group the child's imagination is high, curiosity and guessing it are very sharp. Therefore, the teacher in educating early childhood must be precise in giving pictures and motivations so that the children's imagination develops well.

The role of the teacher evaluator is also essential because through evaluations conducted both teachers and parents will know the weaknesses and strengths of the students so that there is no lagging understanding of children [7]. Student strengths are developed through the role of parents in preparing facilities for the children and the provision of facilities is expected to develop children's talents to the fullest.

A child's education through the stages of sensitive periods or important periods in the lives of children who are free and safe. This sensitive period or important period begins with a 
period of imitation or copying. For example: a child who sees their parents cooking then will imitate it through the media playing cooking. In addition, a child who sees his parents or the environment talking loud and rude will imitate it by talking roughly too.

The imitation or copying period is a very appropriate time to provide knowledge to the children. Imitation also becomes a very vulnerable period when parents give examples of bad behavior. Children's development through imitation will develop very well when the family is warm. A warm family will create peace in the hearts and brains of children so that children easily receive positive knowledge that comes from their families.

The curriculum is adapted to the facilities and infrastructure provided by institution which are usually focused on the physical and psychological development of children. Physical development is usually in the form of children's motor teaching, basic forms of motion, physical fitness, and stimulation through games. Psychological development is usually in the form of moral, religious, and ethical teaching behavior [8] Physical and psychological development is carried out in stages adapted to the child's age and development.

Early childhood teaching is carried out by special methods. Teaching methods are adapted to the children's development. However, before finding a method that is suitable for the children, environmental recognition is usually conducted initially. The introduction of the environment in the form of an introduction between educators and students, an introduction to students, and an introduction to the school environment. The introduction of the environment aims to create comfort and safety in the students.

Physical development used in the form of simple games. a simple game made to minimize student injuries. In addition to games, rhythmic activity is also an activity carried out outside the classroom. Rhythmic activity is used for the purpose of refreshing the children's brain. Although to refresh the children's brain, the basic movements of rhythmic activity are educational tools because the movements are visual forms of daily activities.

The game method can also be done in class. For example children's fine motor teaching is done by arranging blocks, teaching about colors through colored objects that are around, and learning sounds using tools that can be a source of sound. Games are usually called game education. Educational games are used because of the nature of children who are still happy to play. In this case, educators make an effort so that learning is carried out in children's interest [4].

In addition to the teacher's role, the role of parents in the learning process also determines the results of the child's learning process. Parents play a role as a companion in children's learning. Parents are also facilitators in providing all of the children's school needs. Not only academic teaching but also parents do teaching in terms of morals and ethics. Parents must set a good example for their children. In this case, the task of parents is to teach understanding of the good and bad things. In addition, parents also become a companion for children to explore, imagine, and play. Parents also instill the foundations and basis of education for their children or commonly called pedagogical functions. In implementing pedagogical functions, parents must create a comfortable and peaceful atmosphere so that children are interested in learning .

Overall, Early Childhood Education Program is carried out with a variety of methods. The method used is adapted to student development [9]. The method is carried out in stages from general to specific. Children's learning is also carried out with modifications. Modifications to learning are applied so that student activities are not monotonous. The series of learning begins with planning to create comfort in learning. Children's learning can be adapted to technological development. However, parents or educators must limit children in their use. Direct interaction with nature can also be used in the learning process. This is done 
so that children record all learning directly because early childhood is in its golden period. The child's golden period must be taken care wisely. In the golden age, parents and educators must provide appropriate knowledge so that children have good personalities in the future.

\section{RESEARCH METHOD}

Data collection techniques in the research are in the form of interviews and observations. Interview is the process of collecting data through questioners and interviewees. The purpose of the interview is to find out in depth the appropriate method of teaching children/young learner. In addition, the interview aims to find out the problems of children during the adaptation period. The subject of the interview is the leader in the relevant school that acts as the coordinator and educator. The observation process takes place when the researcher enters the school environment. The subjects of observation were children and educators. Validation of research data used triangulation and reference material [10]. Triangulation is testing the truth of the data by comparing it with external data from other sources. In addition, the authors also use references as material for confirmation of the correctness of the data.

\section{RESULTS AND DISCUSSION}

Adaptation to a new place and condition is difficult for children. Usually, when in a new place and meet new people the children will feel scared, ashamed, and the children will tend to be quiet with confusing behavior. Therefore, an introduction to the school environment, teachers, and other friends is needed so that children can adapt and feel comfortable in their school.

In the first week parents are asked to accompany their child to see the child's interests, estimate whether or not the child wants to be educated, and know the child's ability to adapt to new conditions. After one week parents have the right to decide whether or not to send their child to school. When parents feel confident, the following week parents are not allowed to wait for their children at school.

Orientation in this second week students have become the responsibility of teachers at school. Parents need not worry if the child cries because it is an adaptation process. Constantly awaiting the courage of the child does not immediately appear, and this hinders the child's independence in interacting with others. In this second week's orientation the teacher will introduce each other between students by doing small group games, each group named an animal, fruit, or animated character. In addition, each child will be required to wear an animal drawing paper hat, each child with a different picture to make it easier to remember and recognize. This method is considered effective even though there are some children who are still unable to adapt it is considered normal because the ability of each child is different.

After students feel comfortable with the conditions of the school environment, the teacher will introduce "game education" as a starter in the learning process. Game education is a method of training children's motor movements. Like a children's game in general, how to apply the game education is divided into several groups, then each group will compete to win the game. Some educational games applied in schools such as rubber band relay, ball relay, Engrang relay, composing puzzles, stacking blocks, guessing pictures and chained messages.

The main purpose of this educational game is so that children can get to know their friends and train their children's cohesiveness in groups. When children are accustomed to working together from an early age later children will be easy to work with anyone. Another 
goal of game education is also as a means of physical movement, responsiveness, and children's intelligence. In addition to game education, school also provides an easy breakthrough to remember, namely through singing with movements.

Children like things that are happy like singing while clapping or accompanied by movements. Schools make it as an application in the delivery of knowledge. For example, to teach children to perform ablution, the teachers sing while giving the sequence of movements from washing hands to feet. Here the child will mimic the movements and singing delivered by the teacher, although usually the child does it while running, joking with his friend that has become a characteristic of children [11].

To avoid boredom in singing and movement, the teachers always update the style of movement and song. This renewal comes from the ability of the teachers themselves and inspiration from Google or other mass media. In this teaching children are usually quicker to remember because children like and feel happy so they often sing songs that children learn at school. This teaching method is applied in every learning theme such as the introduction of letters, numbers, reading, mathematics, and others.

In addition to learning while playing school also instills discipline. Discipline is a good trait and must be embedded in everyone for the provision of success. The basic introduction to the discipline made by the teacher include, children are required to greet and greet the teacher when they come to school, children are required to arrange their shoes on the shoe rack that has been provided, line up before entering class, pray before and after the learning process, and tidy up toys or equipment that used with the teacher. Beside, the teacher will give a gentle reminder to the child if the child violates, usually the reminder accompanied by punishment for singing, apologizing, and easy questions such as guessing the name of a fruit or animal.

Although it is felt negligible but it has a good impact to the nature of the child. Children will get used to and begin to understand the order of their routines at school and the teacher will give understanding to children to apply it at home [12]. It is not easy and every child has a different natural character, but the name of the effort to instill good habits does require a long process and time.

To optimize the ability of early childhood intelligence at school divides classes into two types, namely center and area classes. The center class is a class that specifically teaches one day of learning content. For example on Monday the theme of learning is reading, then in one day the learning is specifically for reading. The center class aims to make the child more focused on mastering and understanding the material presented. Usually this class is for children aged three to four years or children who have difficulty focusing and mastery of the material.

In contrast to center classes, area classes are classes that require a child to study three to four learning content in a day. How to apply this center class by dividing classrooms into three to four areas that are named such as, mathematics area, language area, art area, and music area. In one area can handle four to six children who will take turns in each area. Usually this area class is for children aged four years to six years. The implementation of this area class ranges from twenty minutes to thirty minutes with interludes games or yells so that children do not get bored. Teaching in center and area classes must be in a happy and pleasant atmosphere, avoid feeling scared, uninspired, and bored.

In addition to optimizing intelligence in children, schools also facilitate extracurricular activities to develop the talents of their students. Extracurricular activities include religious, tambourine, and dance. Extracurricular activities carried out on Saturdays for three hours. In this extracurricular the teacher will direct the children to understand that they have talent, and that talent so that the better it needs to be trained. To increase the enthusiasm of 
extracurricular children, the teacher usually performs every three months. Through the stage the children will be excited and feel appreciated. In addition this stage will increase experience, courage, and confidence in children because children must perform in front of the teacher, parents, and their friends.

The performance is conditional for students who can master the subject taught. While every child at school will want to look like other friends, so that the performance is divided between the performers this month and the following month. In this case the teacher gives an understanding that those who perform first are children who have memorized, for those who have not memorized the practice again and advance to the next month's stage [13]. Thus the students will begin to think that they must join extracurricular activities in order to perform, and indirectly this encourages the enthusiasm of children to pursue their talents.

Schools also have achievement targets so that the students have good social interaction. In its realization once a month the teacher and children will walk around the surrounding village environment. The goal is that children recognize the environmental conditions around their school. When walking around the village, the teacher will bring the child to a stop at the icons that are around the village environment, such as mosques, rice fields, parks, and inscriptions. In addition to developing social interaction, the activity of walking around the village is also as direct education. Children will see activities carried out by people in the places they visit, for example when passing through the rice fields there will be people who are hoeing, doing the fields, planting rice and so on. At that time the children will ask many questions to the teacher who he is, what he is doing.

In going around the teacher will explain what is in the place visited so the children will understand. This method is proven effective for early childhood learning, because the process is the children see firs and the teacher gives an explanation of what the children see. After walking around and resting for a while, the teacher will ask what they have encountered during the tour, this trains the children in concluding, remembering, and assessing the extent of the children understanding.

In Friday activities, children will be invited to clean the school environment. Usually the children will be asked to collect garbage and throw it in the trash. The children will also be invited to arrange objects that are messy and the children will also be taught how to wash their hands, brush their teeth, and toilet training. Healthy and clean Friday activities are intended so that the children have a healthy and clean personality, and it is expected that the children will be able to be independent in taking care of themselves [14].

In addition to gymnastics and leisurely strolling, once in a month the school also invites students to swim. This activity is intended to stimulate the motor and intelligence of children to actively develop. Another goal of sports activities is expected so that children have a healthy body, fit, and have a strong immune system.

An increase in the sense of nationalism in the students, it is also held the introduction of Pancasila (Five Principles) as the basis of Indonesia. The introduction of Pancasila, which is applied in the form of good character planting as a child of the nation, of course uses a simple understanding. Every Monday and commemorating historical days students conduct a flag ceremony with their own trained student officers. Although not as smooth as a ceremony in general, this needs to be done so that the child knows and trains the courage of the child while being a ceremonial officer.

The teacher also teaches national anthem and national songs to the students, as well as the introduction of veteran figures in Indonesia. In addition, as a basis for the introduction of statehood, at least students know the president and vice president in Indonesia, and of course what is meant by the president. Another important basic thing is the color of the flags and the 
Garuda bird on the Pancasila. The introduction of Pancasila and statehood is important, because later on the children will live in Indonesia in which there are rules and norms that apply.

Every child is born with different abilities, be it intelligence, talent, physical strength, and social skills. Therefore, in educating their students, teachers certainly find convenience and difficulty. The ease that is found in early childhood teachers is innocence in the children. The innocence of children makes it easy for teachers to provide understanding and instill a thing for whatever reason the child will accept it. Because of their innocence, all behaviors or things that children see will be easily captured and applied. That is why teachers and parents must give examples of good things to children so that children imitate these good behaviors and apply them to form a good personality [15].

Instead parents and teachers must keep children from negative behaviors and things that can foster negative traits in children. Control and selective education in children is needed to guide children to have good character and attitudes. Selection can be done such as watching how the child's behavior, what is said by the child, the child's playing environment, and the shows seen by children. Supervision of these things needs to be done so that children continue to develop at the age according to their age [16].

Some difficulties faced by early childhood teachers are when children have learning obstacles. In this time the teacher must have a method to facilitate the children who have difficulty in learning. For children who have difficulty in recognizing numbers and counting, the teacher will introduce them through toys or objects that attract children's attention. The object is like a block that is colored prominently and there are numbers written on it. Here the children will be asked to group the same color after which the child is led to count each color group. To introduce the numbers, blocks are arranged to form numbers. In addition, recognition of letters and numbers can also be done by writing on the board and when the teacher writes while saying terms that are easy for children to remember. The pronunciation of the term is like the letter "B" in the front, and so on. Putting good provisions in children from an early age is the provision of children in the future as the next generation of quality nation. Parents and teachers are important figures for the children to develop and grow into fully human beings.

\section{CONCLUSIONS}

In the learning process, the children under 7 years old in the city of Surakarta are involved in every interaction as much as possible. Children are invited to go directly to better understand the knowledge delivered. As in school activities, the children walk around the environment and the teachers explain what they see. It was considered suitable with the development of children who basically have high curiosity. In addition, songs and movements that mimic a thing are considered very appropriate for instilling the concept of objects in the children. The application of religious values such as recitation learning is also very helpful in inculcating children's religious values. In addition to growing children's religious value, memorization of letters also maximizes the functioning of the brain. In addition, the class setting in the school is very appropriate because the children can focus on something that is learned because of the supportive classroom conditions.

Student learning methods are used in a balanced way. Balanced learning will produce student assessment instruments. However, student-learning methods are also flexible in that their use is adapted to the character of each student. Not only focus on general knowledge, but 
also learning in schools teaches religious knowledge, instilling balanced social and religious attitudes in order to produce competent students at the next level.

\section{REFERENCES}

[1] K. Buehler et al., "Early childhood education," in College Student Voices on Educational Reform: Challenging and Changing Conversations, 2016.

[2] P. L. Ackerman, "A theory of adult intellectual development: Process, personality, interests, and knowledge," Intelligence, 1996.

[3] A. N. Geddis, "Transforming subject-matter knowledge: The role of pedagogical content knowledge in learning to reflect on teaching," Int. J. Sci. Educ., 1993.

[4] J. H. Flavell, "Metacognition and cognitive monitoring: A new area of cognitivedevelopmental inquiry," Am. Psychol., 1979.

[5] E. B. Hurlock, "Social psychology (2nd Ed.).," Psychol. Bull., 1945.

[6] P. Prinzie, P. Onghena, W. Hellinckx, H. Grietens, P. Ghesquière, and H. Colpin, "Parent and child personality characteristics as predictors of negative discipline and externalizing problem behaviour in children," European Journal of Personality. 2004.

[7] J. Bawane and J. M. Spector, "Prioritization of online instructor roles: Implications for competency-based teacher education programs," Distance Educ., 2009.

[8] A. S. Lillard, M. D. Lerner, E. J. Hopkins, R. A. Dore, E. D. Smith, and C. M. Palmquist, "The impact of pretend play on children's development: A review of the evidence," Psychol. Bull., 2013.

[9] J. Whitaker and A. Tonkin, "Playfull endings: Making meaning at the end of life," in Play and Playfulness for Public Health and Wellbeing, 2019.

[10] R. Bogdan and S. K. Biklen, "Foundations of Qualitative Research for Education," Qual. Res. Educ., 2007.

[11] M. de Onis and F. Branca, "Childhood stunting: A global perspective," Maternal and Child Nutrition. 2016.

[12] A. Waldman, E. O'Connor, and G. I. Tennekoon, "Childhood multiple sclerosis: A review," Mental Retardation and Developmental Disabilities Research Reviews. 2006.

[13] A. Bhadoria, K. Sahoo, B. Sahoo, A. Choudhury, N. Sufi, and R. Kumar, "Childhood obesity: Causes and consequences," J. Fam. Med. Prim. Care, 2015.

[14] M. L. Courage and J. E. Richards, "Attention," in Encyclopedia of Infant and Early Childhood Development, 2008.

[15] K. B. Gunter, H. C. Almstedt, and K. F. Janz, "Physical activity in childhood may be the key to optimizing lifespan skeletal health," Exerc. Sport Sci. Rev., 2012.

[16] K. Saddhono and M. Rohmadi, "A Sociolinguistics Study on the Use of the Javanese Language in the Learning Process in Primary Schools in Surakarta, Central Java, Indonesia." Int. Edu. Stu., vol. 7 no.6 pp 25-30, 2014 